Article

\title{
Smart Villagers as Actors of Digital Social Innovation in Rural Areas
}

\author{
Nicole Zerrer * and Ariane Sept \\ Dynamics of Communication, Knowledge and Spatial Development Research Department, IRS-Leibniz Institute \\ for Research on Society and Space, 15537 Erkner, Germany; E-Mails: nicole.zerrer@leibniz-irs.de (N.Z.), \\ ariane.sept@leibniz-irs.de (A.S.) \\ * Corresponding author
}

Submitted: 22 April 2020 | Accepted: 3 July 2020 | Published: 14 October 2020

\begin{abstract}
Digital social innovation (DSI) is commonly associated with cities. However, DSI is not limited to urban space. In rural areas, it is the inhabitants themselves who start and push digitalization projects, and collaborate with professional actors from the outside. These innovators see digitalization as a chance to solve rural problems such as scarce mobility, declining community interactions, demographic change, or urban-rural digital divide. In consequence, DSI such as smart community centers, digitally managed car-sharing, or community apps also emerge in rural areas. The article seeks to better understand the different actors responsible for the rural digitalization processes. Based on interviews, document analyses, and field notes, the article focuses on two cases in rural Germany: Wesedun is part of a regional digitalization project empowering villagers to evolve own ideas, and Wokisrab shows off a bottom-up driven digitalization strategy. Both villages are aiming to improve the quality of life. Indicated by these cases and inspired by literature on social innovation, the actor groups are identified as drivers, supporters, and users. Based on the interactions and collaborations of these groups, we introduce Smart Villagers, the bottom-up actors of rural DSI. In order to design governance processes, the results indicate that even though Smart Villagers are motivated, skilled and engaged, they want and need the support of professional actors from the outside.
\end{abstract}

\section{Keywords}

community building; digital social innovation; digitalization; elderly; ICT; rural areas; village development

Issue

This article is part of the issue "The City of Digital Social Innovators" edited by Chiara Certomà (Ghent University, Belgium), Antonella Passani (T6-Ecosystems, Italy) and Mark Dyer (University of Waikato, New Zealand).

(C) 2020 by the authors; licensee Cogitatio (Lisbon, Portugal). This article is licensed under a Creative Commons Attribution 4.0 International License (CC BY).

\section{Introduction}

Digital social innovation (DSI) is usually considered "particularly active in cities [and] has taken off most successfully in urban areas" (Stokes, Baeck, \& Baker, 2017, p. 33). However, we observe numerous digital initiatives in rural areas which also fit the definition of DSI. The manifold challenges of rural areas in Europe range from demographic change (e.g., Christmann, 2017), and service provision (e.g., BBSR, 2018), to urban-rural digital divide (e.g., Salemink, Strijker, \& Bosworth, 2017; Townsend, Wallace, \& Fairhurst, 2015). DSI in rural areas represent a specific type of social innovations, manifested as new ideas, ways, and practices to meet common goals
(Mumford, 2002), that cope with these challenges using digital technologies as tools or digital ecosystems (Bria, 2015; Sept, 2020). Digital initiatives in rural areas provide a broad perspective on how DSI develop in rural areas and what actors are involved in the process of making their villages more liveable places. In the literature, digital social innovators are mainly described in a very general way, focusing on the fact that "innovators, users and communities collaborate" (Bria, 2015, p. 9), the forms and technical means of collaboration (e.g., van Dijck, Poell, \& Waal, 2018) or looking at specific phenomena such as fab labs (e.g., Diez, 2012; Fleischmann, Hielscher, \& Merritt, 2015) or crowdsourcing (e.g., Aitamurto, 2012; Certomà, Corsini, \& Rizzi, 2015). While initial studies fo- 
cus on the driving actors in rural DSI (e.g., Sept, 2020) or analyze smart citizen participation in cities (e.g., Capra, 2016; Cardullo \& Kitchin, 2019), the characteristics and roles of the broader field of actors involved in DSI in rural areas have hardly been addressed in existing literature, even though the knowledge of actors in rural DSI will be beneficial for designing governance processes and support. An actor-oriented approach is required regarding social innovation in rural areas, "as such a perspective better allows the analysis of the self-organising practices of actors involved in rural development" (Neumeier, 2017, p. 43). Therefore, we seek to better understand the individual actors who take on the responsibility for the digitalization processes of their villages. Our question is: Who are these digital social innovators in rural areas, and which roles and characteristics can we attribute to them?

As we are especially interested in rural areas, we focus on two German villages, Wesedun in North RhineWestphalia and Wokisrab in Brandenburg which are particularly recognized for their digital initiatives.

This article continues with a literature review developing a perspective on characteristics of actors of social innovation in rural areas and connects these debates to literature on DSI (Section 2). Afterwards, we present the DSI initiatives in the two villages (Section 3). This is followed by an analysis of the actors' roles in the DSI. Based on these findings, we introduce the notion Smart Villagers as central actors in rural DSI and elaborate their characteristics (Section 4). Finally, we conclude with some considerations on how our insights might be used for other rural DSI, emphasizing also the limitations of our research (Section 5).

\section{Social and DSI in Rural Areas}

DSI is defined as:

A type of social and collaborative innovation in which innovators, users and communities collaborate using digital technologies to co-create knowledge and solutions for a wide range of social needs and at a scale and speed that was unimaginable before the rise of the Internet. (Bria, 2015, p. 9)

In Europe, the idea of DSI has been promoted and introduced into policy and research debates by the DSI4EU project, funded by the European Commission (Stokes et al., 2017). In their mapping, the authors mentioned over 1,000 DSI projects, most of them in Western and Southern European cities (Stokes et al., 2017, p. 33), while, "the application and usability of ICT in the context of a village remained underdiscussed in the literature" (Visvizi \& Lytras, 2018, p. 1). Although European approaches on smart villages refer to social innovation and digital technologies, these remain "two rather separate discourses" (Slee, 2019, p. 635), and, apart from policy papers, DSI is hardly discussed for rural areas
(Sept, 2020). Nonetheless, it has long been shown that broadband access contributes to sustainability of rural life (e.g., Townsend et al., 2015), and we can observe that villages use new technological possibilities, combining the innovations of digital technology with new social practices. Respectively, it is also possible that the apparently high concentration of DSI in cities is due to rural areas receiving less attention from researchers, a phenomenon that has long been known as urban bias (Lipton, 1977). Regarding company-level innovation, for instance, Shearmur noticed an "inherent urban bias to innovation studies" (Shearmur, 2017, p. 452), although innovations outside agglomerations receive more and more attention (Eder, 2019).

For studying DSI actors in rural areas, we therefore rely on research insights to social innovation. The amount of research on social innovation in urban and regional development (Nyseth \& Hamdouch, 2019) has been growing since the 1990s with increasing numbers of studies since 2003 (Howaldt \& Schwarz, 2019; van der Have \& Rubalcaba, 2016). Although the vast literature on social innovation shows "a variety of conceptual approaches" (Christmann, 2020, p. 425), Mumford's definition of social innovation as "the generation and implementation of new ideas about how people should organize interpersonal activities, or societal interactions, to meet one or more common goals" (Mumford, 2002, p. 253) received particular attention (Christmann, lbert, Jessen, \& Walther, 2020, p. 499). We refer to this definition because it distinguishes social innovation from other types of innovation but acknowledges that innovations may have social, technological and economic aspects and can happen on all territorial levels.

Recently, social innovation in European rural areas has gained attention (e.g., Bock, 2016; Christmann, 2017; Fink, Lang, \& Richter, 2017; Noack \& Federwisch, 2019; Richter, 2016). Rural social innovations are frequently characterized by the fact that they are not perceived as such by the local actors themselves but are presented as solutions to existing problems (Christmann, 2019 , p. 236). Rural areas have always been used as experimental spaces; often, it was artists or alternatives who came to the countryside to try something new (Christmann, 2019, p. 236). Accordingly, many works focus on the initial impetus for social innovation in rural areas being external factors (e.g., Butkeviciene, 2009; Neumeier, 2012). For example, in his "proposal for a stronger focus on social Innovations in rural development research," Neumeier assumed that "it is likely that the initial impetus for innovation is triggered by external factors, as ideas or the identification of a need to change one's behavior very seldom arise in a vacuum, without any external influence or stimulation" (Neumeier, 2012 , p. 63). Studies on rural social innovation based on "concepts of neo-endogenous development also acknowledge that...for certain aspects external knowledge and resources will be required" (Bosworth et al., 2016, p. 443). Noack and Federwisch empirically "examined 
the role of external factors and cross-border constellations of actors" (Noack \& Federwisch, 2019, p. 106) in rural social innovation initiatives, showing that rural innovation initiatives are likely to "draw on urban knowledge and practices" (Noack \& Federwisch, 2019, p. 106). Furthermore, studies focus on specific actors, for example social enterprises (e.g., Richter, 2017; Richter, Fink, Lang, \& Maresch, 2020), or the process of successful social innovation (e.g., Bock, 2016; Bosworth et al., 2016; Neumeier, 2017). Meanwhile, empirical knowledge of the different roles, actors are embodying, in the process of rural social innovation, is still scarce (Marini Govigli et al., 2020, p. 3), but, as Neumeier demands, "to understand social innovation in rural development fully there is a pressing need for more grounded empirical case study research" (Neumeier, 2017, p. 43).

Studies that deal with social innovation in general provide helpful references to different actors and their roles (e.g., Butzin \& Terstriep, 2018; Terstriep, Kleverbeck, Deserti, \& Rizzo, 2015). Butzin and Terstriep distinguish "developer, promoter, supporter and knowledge provider which come from the public and private sector as well as civil society" (Butzin \& Terstriep, 2018, p. 78). According to them, developers initiate and operate the innovation. Promoters are partners that provide equipment, funding or connections to policy programs. Supporters facilitate the diffusion of social innovations and knowledge providers offer specific knowledge relevant to the development process (Butzin \& Terstriep, 2018, pp. 78-79). They underline that individual actors are not strictly linked to one role. They may take on several roles or switch between different roles over time. Therefore, the roles are not performed statically but in a dynamic process.

In contrast to these insights from social innovation, actors in DSI are described as "innovators, users and communities [who] collaborate using digital technologies to co-create knowledge and solutions for a wide range of social needs" (Bria, 2015, p. 9). This means that previously separate groups of actors now overlap and co-create knowledge and solutions: Users become producers and the other way around. This is reminiscent of Butzin and Terstriep's idea that actors can change their roles within processes of social innovation. Next to the roles of actors, one must, however, in the case of DSI also consider the role of digital technology:

Technology which drives collaboration, or is explicitly outward-looking, is at the heart of most DSI. Specifically, of the four most commonly used technology groups, three directly facilitate and rely on collaboration or network effects (Social Media and Social Networks; Crowdsourcing, Crowdmapping, Crowdfunding; Peer-to-Peer Networks). (Stokes et al., 2017, p. 27)

To summarize: Detailed empirical insights into DSI in rural areas are still rare. If we want to better understand rural
DSI, we must draw on the discourses on $\mathrm{SI}$ in rural areas and urban DSI. This results in two focuses: 1 ) the actors involved and their roles within DSI initiatives and 2) digital technology and its contribution to cooperation and community-building in villages. In this article, we concentrate on the first, using an actor-centered approach (Neumeier, 2017, p. 43).

\section{Digitalization Projects in Two German Villages}

\subsection{Research Design}

The villages Wokisrab and Wesedun belong to the so called structurally weak, rural regions in Germany (BBSR, 2017; BMWi, 2017) where the population is shrinking faster than average (BBSR, 2018). Both villages have less than 1,000 inhabitants and face problems of demographic change, missing or scarce public and private services, and consequently long distances to shopping facilities, workplaces, educational, and cultural opportunities. To guarantee the anonymity of our interlocutors, we use pseudonyms for their names. However, as we were especially interested in some of the actors' characteristics, such as age, gender and profession, these characteristics remain unchanged. To increase anonymity, pseudonyms are also used for the names of the two villages. Both villages have been chosen because they have attracted attention in the media, in policy papers, or during spatial development conferences through particularly innovative, digitally supported projects. Thus, they not only show new practices of collaboratively using digital technologies but are also discursively marked as innovative (see Hutter, Knoblauch, Rammert, \& Windeler, 2018, pp. 20-21); and therefore we considered them examples for DSI.

The field work in the villages was carried out between July 2019 and February 2020. Inspired by the ideas of a focused ethnography (Knoblauch, 2005), we combined semi-structured expert and digital-biographic interviews with document analysis and participant observations. In Wokisrab 13, and in Wesedun 15 interviews have been conducted, transcribed, and analyzed. 33 documents complemented the data. Furthermore, we conducted participant observations during local digitalization courses and special events (such as a summer festival, the formal delivery of a shared village car, or networking events). We took a 'field-observer role' (Knoblauch, 2005) during our observations, with a focused approach over several short-term field visits, instead of long-term visits.

\subsection{Wokisrab: Building Up Community}

Wokisrab is located in the federal state of Brandenburg, around $80 \mathrm{~km}$ from Berlin city center. 183 inhabitants live in Wokisrab, around 20 of them are children and teens under 18 . The village is a typical, one-street village with a traditionally agriculture-based economy. During 
GDR times, a large-scale agricultural cooperative was the main employer. Today, only a few inhabitants live on agriculture. The only village store and pub had closed during the 1990s. The closest supermarkets and a train stop are $8 \mathrm{~km}$ away. Bus service runs irregularly four times a day on weekdays. Mobile telephone and Internet connection are weak all over the village. Cable broadband connection is comparable to urban areas in Germany at $50 \mathrm{MBit} / \mathrm{s}$ (Bundesnetzagentur, 2020).

We perceive the community of Wokisrab in a process of rebuilding after suffering the losses of infrastructure, employment and population since the end of the GDR. According to the villagers, the spirit of community was completely lost during the 1990s: Inhabitants mostly concentrated on their own private lives. The village has been described as a sad and messy place where "everybody is on bad terms with everybody and nobody [can] get anything going" (D1_104). The first step towards reuniting as a community was initiated by a newly elected village head in 2008. After retirement, she moved to Wokisrab, founded the Village Association, and successfully established a small village newspaper to foster communication and information. A local graphic designer, Daniela Motz, voluntarily took over the responsibility for composition and layout of the newspaper. Another villager, who was professionally engaged with control systems, started building a village website providing historic information and announcing current developments and events: "There are no meeting points anymore. But the small newspaper gives the possibility to spread information. And of course, the same is [true] for the homepage" (D1_I03).

Another step was initiated by Barbara Groß and Werner Titz, a couple who also moved to Wokisrab after their retirement. They bought the vacant former village store and reopened it as a multi-use space. Since 2018, twice a week, the place is used as café, bar, and meeting place, and special events take place irregularly. Additionally, it also serves as the first and only public WiFi Hotspot in the village. Recognizing that a public WiFi Hotspot is useful and necessary marked the start of integrating digital technologies for the improvement of village life. Since the mobile network is unreliable, especially people temporarily living and working in Wokisrab, visitors and kids benefit from the hotspot.

In 2016, Werner Titz became the new head of Wokisrab, and Barbara Groß the chair of the Village Association. According to several villagers, their engagement is the reason why the village community restarted. Their new activism also led the village to enter a village development competition in 2017. Birgit Zuse, a staff member of the district administration, had noticed the new activism in Wokisrab and proposed that the village participates in the competition. A group of around 15 inhabitants, including Werner Titz and the Village Association, started to think about a possible future for the village and put together an application based on some existing village projects. These projects were mainly analogue, such as a bee pasture, an insect hotel, or a table tennis table. The village application won the competition on district level and qualified for the next round on state level. Overwhelmed by their success, the group developed a new village strategy focusing on chances of digitalization to deal with current problems such as mobility and community building. They began to "really think long term, where do we want to see our village in the future....And that's how we realized that it is important to take the villagers and the village with them into the digital age" (D1_I01). By preparing the competition, the group created new ideas on how to use digitalization to develop the village.

The village community came up with four main ideas. One of them was a shared village e-car, a village internal car-sharing program using a digitally managed calendar and administration system. Two other ideas were proposed by a young engineer, Gerd Neumann: A digital communication platform and a shared village database of photos and documents. In order to establish basic communication skills, a digitalization course was planned, too. In the Brandenburg-wide village competition, Wokisrab won a special award for their strategy to deal with challenges of the digital change. As an additional prize, the district administration, again driven by Birgit Zuse, offered a digitalization course, executed by the district's adult education center, directly in the former village store. Content of the course has been decided collectively by the participants.

In 2019, the district administration invited tenders for alternative mobility, and the Village Association of Wokisrab received funding for buying an e-car. Gerd Neumann took over the responsibility to find the right application to manage the village e-car. After researching commercially available apps for car-sharing via the Internet and by recommendation of other villages, he invited three firms for tenders. Decision criteria included the price and usability for users as well as administrators. Two days before the official inauguration of the village car, the application was presented and explained within the digitalization course. In February 2020, the village car arrived in Wokisrab and is now in use.

\subsection{Wesedun: Organized and Self-Confident}

Wesedun is located in the federal state of North RhineWestphalia. 780 inhabitants currently live in Wesedun, with 50 people being employed within the village. 65 inhabitants are between 14-18 years. Since Wesedun has no thoroughfare and is surrounded by a wooded mountain range and a big river, its economy has traditionally been based on tourism and flower farming. Local tourist attractions include a castle with garden, a long-distance cycle track and a yaw-rope passenger ferry. It is a $5 \mathrm{~km}$ drive to the core city, Bachingen, where basic supplies, education and work are available.

Over 10 years ago, there was an adequate infrastructure in Wesedun including a butcher's shop, post office, 
hairdresser, bank office, school, supermarket, bars, and restaurants. Today, only the kindergarten, bakery, two guesthouses, three bus stops, and a train station are still present. The train is an unusual advantage. Every hour a train leaves Wesedun towards a university city. The quality of the digital infrastructure is described as inconsistent:

The WiFi speed is brilliant. This was also our reason to start a project on digitalization. We have $100 \mathrm{Mbit} / \mathrm{s}$ everywhere in Wesedun. But this is just since 2017. The mobile reception is highly fragmentary, with every provider you have reception but on different spots in the village. None is village-wide. That means for tourists arriving at the riverside, if they have the wrong provider, they are unlucky. (D3_I01)

We describe the community of Wesedun as organized volunteers. There is a long tradition of local clubs and structured volunteer engagement in the community. The Club Association represents a broad variety of clubs such as the Catholic Women's Union or the Sports Union. There are also other organized groups such as a flower and a hiking group. The volunteers focusing on village development are called 'Village Workshop.' Some inhabitants volunteer on several positions. A lot of this engagement is managed by Gerald Richter. He is the local conservatist, the chair of the Club Association and of the Village Workshop. He has a large influence on the community and takes this responsibility quite seriously and professionally. One interviewee said that the impression of Wesedun is mainly shaped by Gerald Richter and his competent and enthusiastic nature to motivate people (D3_I06). Another one said: "Mr Richter? He is the engine of the whole story. For years he has been the managing director of the district's IT department. Therefore, he has good knowledge but also good contacts. That makes a huge difference" (D3_109). Generally, the community is described as harmonious and sincere, "incredibly well organized" (D3_I02) or "professional, digital and proud" (D3_102).

In 2017, the municipal mayor of Bachingen announced the invitation for proposal for the Digital Countryside (DC) project. Since Wesedun had just recently received an upgrade of their Internet connection, he especially directed this information towards the elected head of Wesedun, who passed it to the Village Workshop (D3_I01).

DC took place in two districts during 2016-2019. The program is financed by the EU and the state. Heike Wittig described the aim of DC as to bring:

The benefits of digitalization into the rural areas. This region we are in is especially rural. That means, the villages especially struggle with demographic change, ageing of society, migration flow towards the cities and many villages are definitely isolated in terms of mobility. Banks, restaurants and shops are closed and the interaction between people is not happening on the garden fences anymore since many inhabitants are forced to commute for labor....Therefore, the goal of DC is to use digitalization for new possibilities to make the rural areas fit for the future. (D3_I02)

15 villages were accepted after they applied with their own ideas. Most ideas concerned the improvement of communication and information. For Wesedun, DC was managed by the Economic Development Corporation of the District with Heike Wittig as the project manager. She advised the villages throughout the process, organized network events, and provided contact and information about service providers and technical solutions.

The Village Workshop in Wesedun had already formulated a development strategy called 'Actionplan Wesedun 2020' with the goal to meet the challenges of demographic change. But besides improving the village website, no digital topic had been part of the development strategy. With the upgraded Internet connection and the call of DC, the group started to ideate about the possibilities of digitalization for the village community. Gerald Richter "put his heart and soul" (D3_103) into specifying the best nine ideas and authoring the application for DC.

Wesedun realized five of their ideas within the funding period. The ideas were divided into two sections: 'demography,' with the highest priority, and 'digital infrastructure.' In order to meet the challenges of demographic change, the focus was to improve the quality of life, mobility, social integration, and autonomy of elderly villagers. Gerald Richter mentioned that:

Especially the demographic change in the village has been the reason for founding the Village Workshop. We wanted to set something against this process and save the quality of life within the village. This was the reason for our digital project. With our application at DC we got the financial support that we needed to realize a project, now we had to think about a digital solution. Without DC the project would most likely not have been digital. (D3_I01)

Subsequently the villagers invented a digital village emergency call application which was programmed and implemented in collaboration with a small tech start-up. With the new application, solitary elderly villagers can get help from other villagers if they find themselves in a non-medical urgent situation. Just by pushing a button on the smartphone, registered volunteers get a notification where help is needed.

Furthermore, Internet courses for the elderly were planned, because "it is not that they cannot understand, it is that they need support by doing their first digital steps" (D3_I01), said Gerald Richter. Eight villagers were trained for 18 months at the adult education center to subsequently give Internet courses to fellow villagers over the age of 65 . In addition to the training of 
these 'village's digital experts,' Wesedun was equipped with hardware for offering Internet courses. The village's Internet courses are regularly fully booked, with additional requests from neighboring villages. The third measure for the 'demography' section is a community application programmed and developed by an applied research institute based on the needs and demands of the villagers. With the application, villagers can share news and information, offer and ask for items and neighborhood assistance. One user said:

The village application is like Facebook for the village. We still speak in direct contact with each other but information is better shared over the app.... I also picked up two, three things which were offered in the 'search \& offer' section. (D3_I15)

In the section of 'digital infrastructure,' the community building was equipped with smart home technology and WiFi by a specifically interested and skilled member of the Village Workshop. The technology is supposed to make the building safer and more comfortable, while giving the villagers insight on smart home technology.

\section{Drivers, Supporters and Users: Smart Villagers in DSI}

In both villages, different types of actors are involved in the process of DSI. On a vertical level, they can be differentiated by top-down actors (professionals from outside of the village) and bottom-up actors (volunteers, belonging to the village). On a horizontal level, inspired by the argumentation in the literature (Bria, 2015; Butzin \& Terstriep, 2018), we can identify three groups of actors: 1) drivers, 2) supporters and 3) users. They are defined based on their specific interest, knowledge, level of engagement and connection to the village. The groups are linked to each other and interact in different stages of the process. Furthermore, actors are not tied to one group: They switch between roles or are part of several groups. For example, users can act as supporters, when testing the new technology. Or drivers that use their own innovations are simultaneously important users. The following analysis of the actor groups will lead to the definition of Smart Villagers in Section 4.4.

\subsection{Drivers}

Inspired by the actor groups 'developer,' 'knowledge provider' and 'supporter' (Butzin \& Terstriep, 2018), we defined the 'drivers' as actors who initiate, operate, represent, and manage the innovation and the other actors in every stage of the process. They are technologyfriendly and enthusiastic about or at least open to digitalization. They are aware of regional problems and push to change the situation. They encourage and motivate the users and supporters. Drivers take gratification from feeling self-efficient in their engagement, raising public awareness, being taken seriously, and having their suc- cessful improvements visible. They are either formally organized volunteers within the village (bottom-up) or professionals outside of the village (top-down).

'Bottom-up drivers' are often retired or new village inhabitants. These actors tend to be voluntarily active people that take on responsibilities. Some even involve themselves with the village administration, a voluntary and unpaid task, in both villages. These characteristics are typical also for general volunteer involvement in villages (Laschewski, Steinführer, Mölders, \& Siebert, 2019, p. 35) and social innovation in rural areas (Noack, 2017; Noack \& Federwisch, 2019). The drivers come up with new ideas, motivate, and manage other volunteers, look out for funding opportunities, write applications, organize the local meeting room, do networking, and represent the DSI in the media, on the municipal and at the district level. Each driver offers specific knowledge or experience useful for the DSI, which is often related to their (former) employment. One interviewee stated:

We are really lucky that some villagers have professional experience on important topics. When someone works for the district government, they know how to address public funding and support. Or the former regional IT manager takes on the position as the village conservationist. But there are also people moving to the village and bringing ideas and input from the outside. (D3_I04)

New inhabitants like Barbara Groß and Werner Titz can play a particular motivating role, as Daniela Motz describes: "We took courage that such a small place like Wokisrab can really have a say....I think if Barbara and Werner hadn't come, nobody would have ever thought of taking part in such a competition." (D1_I06).

A strong dependence on individual actors can pose a risk as individuals may suffer burn-out or illness and thus activities could be halted. This risk is also acknowledged by local drivers like Gerd Neumann "to avoid that then suddenly one person falls away and nothing more happens, I am always in favor of spreading everything over many shoulders" (D1_I10). Indeed, surrounding the main drivers, we find working groups of about 10-20 villagers, be it the Village Workshop or the Village Association. Members contribute with their experience in brainstorming for new ideas, project applications, teaching, programming, installing or managing technology becoming drivers, too. Under the lens of citizen power, we can describe the drivers as leaders, decision makers and cocreators (Cardullo \& Kitchin, 2019, p. 5).

'Top-down drivers' are often professionals, who operate on district level. The Economic Development Corporation of the District, for example, conceptualized DC, applied for funding and gave the initial impulse for ideating on village level. Heike Wittig, as well as Birgit Zuse, give advice and regular impetus to the villages, monitor the process, or mediate between the villagers and the service providers. With regard to Birgit Zuse, 
Barbara Groß describes that "the district keeps us going...and plays a significant role" (D1_I01).

\subsection{Supporters}

The actor group of 'supporters' offers specific knowledge, funding, connections to policy programs and service providers, or other kinds of active engagement requested by the drivers. In contrast to Butzin and Terstriep's (2018) 'supporters,' who mainly facilitate the diffusion of the innovation, our supporters are also to some extent 'promoters' and 'knowledge providers.' They use their experience to advise the drivers as well as other villages about DSI and report their news, thus actively support the diffusion. They enter the process when their support is required but do not actively develop new ideas. Similar to the drivers, 'bottom-up supporters' within the village are volunteers, while 'top-down supporters' outside of the village are mainly professionals. They can also be distinguished by their level of activity: Supporters "partially re-arrange the deckchairs on a ship's deck, but not to determine how the ship is run or its general course" (Cardullo \& Kitchin, 2019, p. 8).

Supporters develop or administrate apps, do layout, advise, correct texts, or give Internet training. Their support activities are often based on, connected to, or part of their professional work, like the engineer Gerd Neumann, who takes responsibility for the car-sharing application. Another example is Hilde Schneider, a temporary inhabitant in Wokisrab, who is working as an editor and supported the application for the car-sharing funding: "That's where I went in and basically did a lot with the formulation of all the documents, I also took up my work as an editor and formulated everything a bit more professionally" (D1_I13). Thus, while research on rural social innovation suggests focusing on driving actors and external impetus, we find that specific local skills are strongly needed to support the drivers.

From the outside, there are also less active supporters, such as political and administrative actors that provide advice and information on measures and funding opportunities, motivate the village to continue, represent the DSI in the public, and provide a network or knowledge about political and strategic planning. It is again often the district level acting as supporter. For example, in Wokisrab, the deputy district administrator explained that "support is now provided by computer courses which are organized by the district adult education center. The costs of this project are also covered by the district, to support this pilot project" (D1_105). While Birgit Zuse is considered a driver, the district administrator and the deputy are described as "not in the front line, but when certain things are said, they are very, very open" (D1_I01) and are, therefore, supporters.

Other important supporters are the tech organizations that collaborate with the villagers to program and develop customized digital technology solutions and content, like the institute for applied research and the tech start-up. A local journalist who reports about village activities also counts as supporter as well as the public financiers like the EU or the adult education center that trained the 'villager's digital experts' in Wesedun.

\subsection{Users}

In line with the definition of DSI (see Section 2), we identified 'users' as an important, yet unnoticed group in rural social innovation. Users not only collaborate with but also motivate drivers and supporters. Hilde Schneider, who supported the funding application, was also an early user of the village WiFi, for her the opening of the former village store "was a great leap in quality, because a WiFi connection was set up" (D1_I13). Users like her are a motivating force. Werner Titz proudly describes her sitting in front of the store: "She lives in the castle and has no WiFi there, she sits here. So, WiFi was the first step. And then we said, now we have to see that we lead people [to broader digitalization]" (D1_I02). Thus, without the users, the DSI would not be successful. Users are part of the village community. Their level of engagement can vary over time. Depending on measures, they can passively use the DSI or actively create interactions. For example, a user can be an active student in the Internet courses while just being a quiet reader on the village application, until eventually posting some news. Besides having personal motives to use the measures, e.g., online banking or online photo books (D3_I12), they perceive the improved community communication as the most important gain: "Meanwhile I know almost 2/3 of the local villagers, many of them I did not know before. I really appreciate that and it is also part of what I understand as 'home"' (D3_108).

Users benefit from using the public village WiFi. They book the village e-car via the application. They communicate through the village application and help the elderly via an emergency application. They learn in the Internet courses and make use of the smart home community hall.

\subsection{Smart Villagers}

As a result of the above described and defined groups of actors, the actively involved actors of all three groups who are residents or have their secondary residence in the village, can be defined as Smart Villagers (see Figure 1). Smart Villagers are visible members of the village community, therefore, on the vertical level, they are bottom-up actors. They are somehow skilled, be it technical, organizational or communicative skills, and they develop additional competences throughout the innovation process. No matter if they belong to the drivers, the supporters, or the users, they share a positive and interested attitude towards digitalization. They are aware of the rural issues and are open to innovative solutions. Hence, they actively use and develop DSI to shape and improve everyday village life. Smart Villagers are self- 
confident about the benefits of their DSI. They do not want to rely on governmental strategies but try to canvass public funding. Through their engagement, they strengthen the community spirit and take gratification from being perceived as a future-oriented and inspiring village. Smart Villagers are the carriers of the digital social change in rural areas. They push forward and motivate others to engage and thus become Smart Villagers, too. To sum up: Smart Villagers can be characterized with their digital positivity, problem awareness, active engagement, motivation, community orientation, responsibility and self-efficiency. On horizontal level, they can be found in all three groups of actors. In the "scaffold of smart citizen participation" (Cardullo \& Kitchin, 2019, p. 5), their form and level of participation correspond to 'citizen power' and 'tokenism': They are inclusive, bottom-up, collective autonomous and experimental.

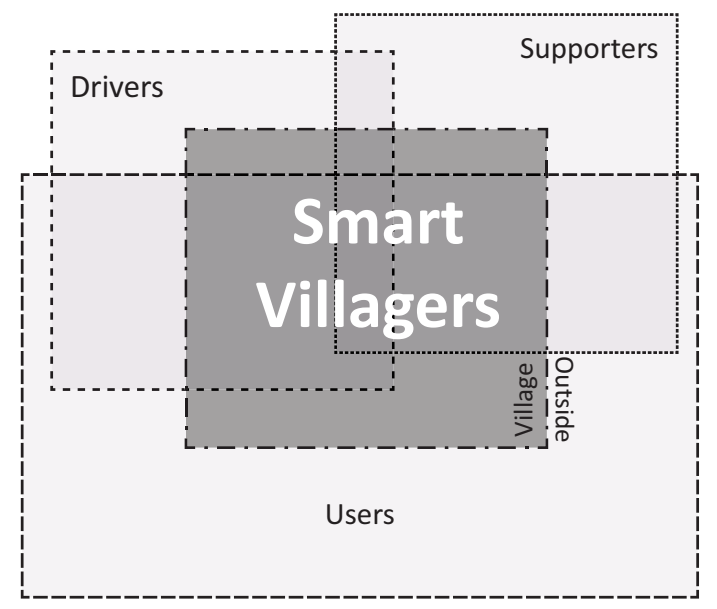

Figure 1. Smart Villagers in rural DSI.

\section{Conclusion}

DSI are a way to cope with typical rural challenges such as demographic change (e.g., Christmann, 2017), service provision (e.g., BBSR, 2018) or urban-rural digital divide (e.g., Salemink et al., 2017; Townsend et al., 2015). The study presented is a step to better understand the rural innovation process. The notion of Smart Villagers introduced here provides insights that can be used to design governance and support strategies in rural development. Aiming to better understand the self-organizing practices in rural DSI, we followed Neumeier's (2017) suggestion to use an actor-oriented approach, and chose focused ethnography to gather data in two case studies.

The specific aim of this article was to understand who the digital social innovators in rural areas are, which roles they have, and which characteristics can be attributed to them. Inspired by the literature on social innovation (Butzin \& Terstriep, 2018), citizen participation in smart cities (Cardullo \& Kitchin, 2019) and DSI (Bria, 2015) we identified three actor groups in our case studies: driver, supporter and user. Our contribution to the scientific discourse is therefore, combining an actor-centered approach on rural innovation with actor perspectives from literature on social innovation and confronting these with empirical data from DSI in rural villages.

As the main result, we condensed our findings and introduced the notion Smart Villagers for the actively involved, bottom-up actors of all three groups. They appear as the core of rural DSI. In both cases we identified a group of 10 to 20 people being the constantly active Smart Villagers. They all bring specific skills and a technology-friendly attitude into the process. As for other social innovations in rural areas (Noack, 2017; Noack \& Federwisch, 2019), we can observe retired, elderly people being especially active Smart Villagers.

Like other research on DSI (Bria, 2015; Stokes et al., 2017), we noticed that the observed villages make use of technology to support and encourage collaboration or community building. Digital technology is used to solve concrete problems. Next to mobility and communication, the needs of elderly villagers were primary fields of application. However, the innovative core is mainly not the digital technology as such or the collaborative technological development but the collaborative way of using and implementing it in the villages.

Rural DSI may be developed by Smart Villagers in a bottom-up process with outside support as in the case of Wokisrab or manifest as a top-down-bottom-up interplay as in Wesedun. We see both ways as promising DSI paths and consider the district level-next to the local oneas fundamental. Professional actors on this level support and motivate Smart Villagers and can offer stability. Or as one interviewee said "volunteers need the assistance of full-time professionals" (D3_106). However, we can also confirm for rural DSI what Neumeier assumed for social innovation: "Processes initiated by the actors themselves, as well as a framework enabling the actors to develop social innovation processes seem to be more promising than purely externally governed processes" (Neumeier, 2017 , p. 39). This means that Smart Villagers with their equally important roles, from drivers to users, must be acknowledged and supported from outside the village.

The explanatory power of this article is limited. We are not able to foresee the further development of the DSI or their long-term impact. A key open question is whether the drivers, who are mainly responsible for the DSI, will manage to maintain their high level of commitment over a long period. In the case that one of the drivers happen to disengage, we are unsure about the consequences for the DSI and the community. To answer these open questions, we plan to revisit the villages by the end of 2020. Another limitation is due to the geographical focus on two German cases; DSI in other European rural areas might significantly differ.

Further research on the long-term effects of DSI in village communities would supplement the results presented and add to the slowly growing field of DSI research. Moreover, a closer look at how the 'social' meets the 'digital' in the case of rural DSI warrants further re- 
search. Additional results in this field can inspire public policy and governance strategies, future Smart Villagers and technology oriented social entrepreneurs.

\section{Acknowledgments}

This work is part of the project 'Smart Villagers: Digitalization and Social Innovation in Rural Areas,' funded and conducted by the Leibniz Institute for Research on Society and Space in Erkner, Germany. We are grateful to the project leader Gabriela Christmann for her continuous guidance and suggestions. Our special thanks go to Nastassja Hofmann and Cecilia Mauceri for proofreading the article; and to all our interlocutors in the two villages for their time and patience. We furthermore thank the three unknown reviewers for providing constructive feedback, which was a big support in the revision phase of this manuscript.

\section{Conflict of Interests}

The authors declare no conflict of interests.

\section{References}

Aitamurto, T. (2012). Crowdsourcing for democracy: $A$ new era in policy-making. Helsinki: Parliament of Finland.

BBSR. (2017). Referenz Kreise/Kreisregionen zu Kreistypen [Reference counties/districts to types of districts]. BBSR. Retrieved from https://www. bbsr.bund.de/BBSR/DE/Raumbeobachtung/ Raumabgrenzungen/deutschland/kreise/ Kreistypen2/downloadangebote.html?nn=443222

BBSR. (2018). Raumordnungsbericht 2017: Daseinsvorsorge sichern [Regional planning report 2017. Ensuring public services]. Bonn: Bundesamt für Bauwesen und Raumordnung.

BMWi. (2017). Fördergebiete der Gemeinschaftsaufgabe "Verbesserung der regionalen Wirtschaftsstruktur" im Zeitraum 2014-2020 [Development areas of the common task "improvement of the regional economic structure" over the period between 2014 and 2020]. BMWi. Retrieved from https://www.bmwi. de/Redaktion/DE/Downloads/foerdergebietskarteab-08-2017.pdf?_blob=publicationFile \&v=9

Bock, B. B. (2016). Rural marginalisation and the role of social innovation: A turn towards nexogenous development and rural reconnection. Sociologia Ruralis, 56(4), 552-573.

Bosworth, G., Rizzo, F., Marquardt, D., Strijker, D., Haartsen, T., \& Aagaard Thuesen, A. (2016). Identifying social innovations in European local rural development initiatives. Innovation: The European Journal of Social Science Research, 29(4), 442-461.

Bria, F. (2015). Growing a digital social innovation ecosystem for Europe: DSI final report. Luxembourg: Publications Office.
Bundesnetzagentur. (2020). Breitbandmessung Karte Deutschland [Broad band measurement map Germany]. Breitbandmessung. Retrieved from https:// breitbandmessung.de/kartenansicht

Butkeviciene, E. (2009). Social innovation in rural communities: Methodological framework and empirical evidence. Socialiniai Mokslai: Social Sciences, 1, 80-88.

Butzin, A., \& Terstriep, J. (2018). Actors and roles in social innovation. In J. Howaldt, C. Kaletka, A. Schröder, \& M. Zirngiebl (Eds.), Atlas of social innovation: New practices for a better future (pp. 78-81). Dortmund: Sozialforschungsstelle.

Capra, C. F. (2016). The smart city and its citizens. International Journal of E-Planning Research, 5(1), 20-38.

Cardullo, P., \& Kitchin, R. (2019). Being a 'citizen' in the smart city: Up and down the scaffold of smart citizen participation in Dublin, Ireland. GeoJournal, 84(1), $1-13$.

Certomà, C., Corsini, F., \& Rizzi, F. (2015). Crowdsourcing urban sustainability: Data, people and technologies in participatory governance. Futures, 74, 93-106.

Christmann, G. B. (2017). Analysing changes in discursive constructions of rural areas in the context of demographic change: Towards counterpoints in the dominant discourse on "dying villages." Comparative Population Studies, 41(3/4), 359-378.

Christmann, G. B. (2019). Innovationen in ländlichen Gemeinden [Innovations in rural municipalities]. In W. Nell \& M. Weiland (Eds.), Dorf: Ein interdisziplinäres Handbuch [Village: An interdisciplinary handbook] (pp. 235-240). Stuttgart: J. B. Metzler.

Christmann, G. B. (2020). Introduction: Struggling with innovations: Social innovations and conflicts in urban development and planning. European Planning Studies, 4(1), 423-433.

Christmann, G. B., Ibert, O., Jessen, J., \& Walther, U.J. (2020). Innovations in spatial planning as a social process: Phases, actors, conflicts. European Planning Studies, 3(1), 496-520.

Diez, T. (2012). Personal fabrication: Fab labs as platforms for citizen-based innovation, from microcontrollers to cities. Nexus Network Journal, 14(3), 457-468.

Eder, J. (2019). Innovation in the periphery: A critical survey and research agenda. International Regional Science Review, 42(2), 119-146.

Fink, M., Lang, R., \& Richter, R. (2017). Social entrepreneurship in marginalised rural Europe: Towards evidence-based policy for enhanced social innovation. Regions Magazine, 306(1), 6-10.

Fleischmann, K., Hielscher, S., \& Merritt, T. (2015). Making things in fab labs: A case study on sustainability and co-creation. Digital Creativity, 27(2), 113-131.

Howaldt, J., \& Schwarz, M. (2019). Soziale Innovation [Social innovation]. In B. Blättel-Mink, I. SchulzSchaeffer, \& A. Windeler (Eds.), Handbuch Innovationsforschung [Handbook on innovation research] (pp. 1-17). Heidelberg: Springer. 
Hutter, M., Knoblauch, H., Rammert, W., \& Windeler, A. (2018). Innovation society today: The reflexive creation of novelty. In W. Rammert, A. Windeler, H. Knoblauch, \& M. Hutter (Eds.), Innovation society today: Perspectives, fields, and cases (pp. 13-31). Wiesbaden: Springer VS.

Knoblauch, H. (2005). Focused ethnography. Forum Qualitative Sozialforschung/Forum: Qualitative Social Research, 6(3).

Laschewski, L., Steinführer, A., Mölders, T., \& Siebert, R. (2019). Das Dorf als Gegenstand sozialwissenschaftlicher Forschung und Theorie [The village as object of social sciences research and theory]. In A. Steinführer, L. Laschewski, T. Mölders, \& R. Siebert (Eds.), Das Dorf: Soziale Prozesse und räumliche Arrangements [The village: Social processes and spatial arrangements] (pp. 3-56). Berlin: LIT Verlag.

Lipton, M. (1977). Why poor people stay poor: Urban bias in world development. London: Temple Smith.

Marini Govigli, V., Alkhaled, S., Arnesen, T., Barlagne, C., Bjerck, M., Burlando, C., \& Górriz-Mifsud, E. (2020). Testing a framework to co-construct social innovation actions: Insights from seven marginalized rural areas. Sustainability, 12(4). https://doi.org/10.3390/ su12041441

Mumford, M. D. (2002). Social innovation: Ten cases from Benjamin Franklin. Creativity Research Journal, 14(2), 253-266.

Neumeier, S. (2012). Why do social innovations in rural development matter and should they be considered more seriously in rural development research? Sociologia Ruralis, 52(1), 48-69.

Neumeier, S. (2017). Social innovation in rural development: Identifying the key factors of success. The $\mathrm{Ge}$ ographical Journal, 183(1), 34-46.

Noack, A. (2017). Elderly people in rural regions as promoters of social innovations and changing knowledge. In K. Svels (Ed.), Proceedings of the XXVII European society for rural sociology congress (pp. 118-119). Krakow: Institute of Sociology, Jagiellonian University.

Noack, A., \& Federwisch, T. (2019). Social innovation in rural regions: Urban impulses and cross-border constellations of actors. Sociologia Ruralis, 59(1), 92-112.

Nyseth, T., \& Hamdouch, A. (2019). The transformative power of social innovation in urban planning and lo- cal development. Urban Planning, 4(1), 1-6.

Richter, R. (2016). Social innovations in rural life worlds. In V. M. Carlow (Ed.), Ruralism (pp. 148-155). Berlin: Jovis.

Richter, R. (2017). Rural social enterprises as embedded intermediaries: The innovative power of connecting rural communities with supra-regional networks. Journal of Rural Studies, 70, 179-187.

Richter, R., Fink, M., Lang, R., \& Maresch, D. (2020). Social entrepreneurship and innovation in rural Europe. New York, NY: Routledge.

Salemink, K., Strijker, D., \& Bosworth, G. (2017). Rural development in the digital age: A systematic literature review on unequal ICT availability, adoption, and use in rural areas. Journal of Rural Studies, 54, 360-371.

Sept, A. (2020). Thinking together digitalization and social innovation in rural areas: An exploration of rural digitalization projects in Germany. European Countryside, 12(2), 193-208.

Shearmur, R. (2017). Urban bias in innovation studies. In H. Bathelt, P. Cohendet, S. Henn, \& L. Simon (Eds.), The Elgar companion to innovation and knowledge creation (pp. 440-456). Northampton: Edward Elgar.

Slee, B. (2019). Delivering on the concept of smart villages: In search of an enabling theory. European Countryside, 11(4), 634-650.

Stokes, M., Baeck, P., \& Baker, T. (2017). What next for digital social innovation? Realising the potential of people and technology to tackle social challenges. Brussels: European Commission.

Terstriep, J., Kleverbeck, M., Deserti, A., \& Rizzo, F. (2015). Comparative report on social innovation across Europe. Brussels: European Commission.

Townsend, L., Wallace, C., \& Fairhurst, G. (2015). 'Stuck out here': The critical role of broadband for remote rural places. Scottish Geographical Journal, 131(3/4), 171-180.

van der Have, R. P., \& Rubalcaba, L. (2016). Social innovation research: An emerging area of innovation studies? Research Policy, 45(9), 1923-1935.

van Dijck, J., Poell, T., \& Waal, M. d. (2018). The platform society. Oxford: Oxford University Press.

Visvizi, A., \& Lytras, M. (2018). It's not a fad: Smart cities and smart villages research in European and global contexts. Sustainability, 10(8). https://doi.org/ $10.3390 /$ su 10082727

\section{About the Authors}

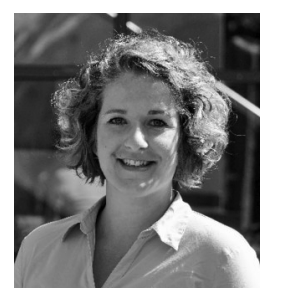

Nicole Zerrer studied Communication Science at University of Muenster, Hawai'i Pacific University, Stockholm University and Freie Universität Berlin. Since June 2019 she has been working as a PhD Candidate and Research Associate at the Dynamics of Communication, Knowledge and Spatial Development research department at the Leibniz Institute for Research on Society and Space in Erkner, Germany. In her ongoing dissertation she focusses on DSI and digitalization in rural areas and asks questions about how mediatization changes everyday life in village communities, especially for elderly villagers. 
Ariane Sept studied Urban and Regional Planning in Berlin and Rome and holds a PhD in Sociology from TU Berlin. Since October 2018 she has been working as a Research Associate at the Dynamics of Communication, Knowledge and Spatial Development research department at the Leibniz Institute for Research on Society and Space in Erkner, Germany. Her main fields of study regard current developments in rural and urban areas, (social) innovations, socio-spatial acceleration and deceleration as well as (European) urban and regional policies. 